\title{
EFEKTIVITAS SEMINAR PASAR MODAL SYARIAH TERHADAP MINAT BERINVESTASI GENERASI MILENIAL
}

\author{
Hesty Rahayu Pangestuti ${ }^{1}$ \\ M. Adam Fernanda ${ }^{2}$
}

\begin{abstract}
Sharia Capital Market Seminar is one of the education and socialization programs organized by the Indonesia Stock Exchange (IDX). The program is one of the efforts made by the Indonesia Stock Exchange to increase public investment interests, especially millennials, which are still quite low due to lack of literacy on the Islamic capital market. This study aims to examine the effectiveness of the Sharia Capital Market Seminar on investment interests in millennial generation. This research is a qualitative research with a random sampling method using purposive sampling technique. The data source in this study is primary data obtained from interviews using online questionnaires via Google Form. The results of this study found that the Sharia Capital Market Seminar educational program was effective in moderating the interest in investing in millennials.
\end{abstract}

Keywords: sharia capital market seminar, investment interest and millennial generation.

\begin{abstract}
Abstrak
Seminar Pasar Modal Syariah merupakan salah satu program edukasi dan sosialisasi yang diselenggarakan oleh Bursa Efek Indonesia (BEI). Program ini merupakan salah satu upaya yang dilakukan Bursa Efek Indonesia untuk meningkatkan minat investasi masyarakat terkhusus kaum milenial yang masih cukup rendah akibat kurangnya literasi mengenai pasar modal syariah. Penelitian ini bertujuan untuk mengkaji efektifitas Seminar Pasar Modal Syariah terhadap minat berinvestasi generasi milenial. penelitian ini bersifat kualitatif dengan metode pengambilan sampel secara acak menggunakan teknik purposive sampling. Sumber data dalam penelitian ini adalah data primer yang diperoleh dari wawancara menggunakan kuisioner online melalui google form. Hasil penelitian ini mendapatkan bahwa program edukasi Seminar Pasar Modal Syariah efektif dalam memoderasi minat berinvestasi generasi milenial.
\end{abstract}

Kata kunci: seminar pasar modal syariah, minat investasi, dan generasi milenial.

${ }^{1}$ IAIN Kudus: hestyr4@gmail.com

${ }^{2}$ IAIN Kudus adam.fernanda18@gmail.com 


\section{PENDAHULUAN}

Aktivitas investasi merupakan hal yang relatif baru bagi masyarakat Indonesia. Investasi adalah komitmen atas sejumlah dana atau sumber daya lainnya yang dilakukan dengan tujuan memperoleh sejumlah keuntungan di masa datang (Tandelilin, 2010). Dibandingkan dengan negara lain, minat berinvestasi masyarakat Indonesia masih terbilang rendah, khususnya investasi di pasar modal syariah. Padahal jika dilihat secara populasi, seharusnya Indonesia memiliki potensi yang tinggi dalam jumlah investor syariah karena penduduk Indonesia sebagian besar adalah Muslim (Khotimah, Warsini, \& Nuraeni, 2011).

Seiring berkembangnya teknologi yang semakin canggih meningkatkan jumlah investor muda atau milenial di pasar modal. Generasi milenial lahir pada kurun waktu antara 1980 hingga 2000-an (Faiza, Firda, \& Dkk, 2018). Berdasarkan data Otoritas Jasa Keuangan (OJK), kelompok usia 16-30 tahun atau yang sering disebut sebagai generasi milenial saat ini berjumlah kurang lebih 64,3 juta jiwa. Namun, kesadaran berinvestasi generasi milenial di pasar modal syariah masih belum terlalu besar. Hal ini disebabkan oleh minimnya literasi mengenai pasar modal syariah.

Literasi mengenai pasar modal syariah di Indonesia masih menjadi suatu tantangan terbesar. Oleh karena itu, Bursa Efek Indonesia menyelenggarakan berbagai program edukasi seperti seminar, workshop, talk show interaktif, dan sekolah pasar modal syariah. Berbagai program edukasi ini juga dilakukan bekerjasama dengan institusi pendidikan terutama di tingkat perguruan tinggi. Karena investor milenial didominasi oleh kalangan mahasiswa yang diharapkan mampu berkontribusi aktif dalam peningkatan investasi di pasar modal syariah (Mega \& Semara, 2015). IAIN Kudus merupakan salah satu perguruan tinggi Islam yang sudah menjalankan program edukasi mengenai investasi di pasar modal syariah secara langsung baik melalui seminar maupun sekolah pasar modal syariah.

Penelitian-penelitian sebelumnya telah menunjukkan bahwa edukasi berpengaruh terhadap minat berinvestasi. Namun, belum ada peneliti yang meneliti secara khusus efektivitas Seminar Pasar Modal Syariah terhadap minat berinvestasi. Penelitian (Khotimah et al., 2011) menunjukkan bahwa sosialisasi berpengaruh positif signifikan terhadap minat investor. Jika penyampaian sosialisasi dilakukan dengan tepat, maka mendorong investor untuk berinvestasi. Sementara itu penelitian (Mubarok, 2018) mengemukakan bahwa sosialisasi dan edukasi melibatkan berbagai informan dan media sosial. Informan yang paling berpengaruh adalah aktivitas perkuliahan yang melibatkan dosen. Sedangkan media sosial yang memiliki kontribusi paling besar adalah media facebook. Kemudian penelitian (Albab \& Zuhri, 2019) menyatakan bahwa edukasi secara simultan berpengaruh signifikan terhadap minat berinvestasi di pasar modal syariah. Selanjutnya penelitian (Prayoga, 2019) menunjukkan bahwa edukasi dan sosialisasi sekolah pasar modal Bursa Efek Indonesia berpengaruh positif signifikan terhadap motivasi membeli saham pada galeri investasi. Berdasarkan uraian tersebut, penelitian ini bertujuan untuk mengetahui efektivitas Seminar Pasar Modal Syariah terhadap minat berinvestasi generasi milenial. Hasil penelitian ini diharapkan dapat menjelaskan efektivitas pelaksanaan program Seminar Pasar Modal Syariah sebagai media edukasi yang memoderasi minat berinvestasi generasi milenial. 


\section{KAJIAN LITERATUR}

\section{Generasi Milenial}

Generasi dalam Kamus Besar Bahasa Indonesia mempunyai arti semua orang yang kira-kira sama waktu hidupnya; angkatan; turunan (KBBI Daring 2016). Seseorang yang menjadi bagian dari satu generasi adalah mereka yang memiliki tahun lahir yang sama dalam rentang waktu 20 tahun. Menurut Manheim (1952) generasi adalah suatu konstruksi sosial yang di dalamnya terdapat sekolompok orang yang memiliki kesamaan umur dan pengalaman historis yang sama. Secara spesifik definisi tersebut kemudian dikembangkan oleh Ryder (1965) yang menyatakan bahwa generasi adalah agregat dari sekelompok individu yang mengalami peristiwa-peristiwa dalam kurun waktu yang sama. Selanjutnya menurut Kupperschmidt (2000) generasi adalah sekelompok individu yang mengidentifikasi kelompoknya berdasarkan kesamaan tahun kelahiran, umur, lokasi, dan kejadian-kejadian dalam kehidupan kelompok individu tersebut yang memiliki pengaruh signifikan dalam fase pertumbuhan mereka (Statistik, 2018).

Istilah milenial pertama kali dicetuskan dalam buku yang berjudul Millennials Rising: The Next Great Generation (2000) oleh William Strauss dan Neil. Generasi milenial (Millennial Generation) adalah generasi yang lahir dalam rentang waktu awal tahun 1980 hingga tahun 2000. Generasi ini sering disebut juga sebagai Gen Y, Net Generation, Generation WE, Boomerang Generation, Peter Pan Generation, dan lainlain. Disebut generasi milenial karena mereka adalah generasi yang hidup di pergantian milenium yang secara bersamaan di era ini teknologi digital mulai merasuk ke segala sendi kehidupan (Yuswohady, 2016).

Berdasarkan hasil penelitian dari Lancaster \& Stillman (2002) Generasi Y lebih dikenal dengan sebutan generasi millenial atau milenium. Ungkapan generasi Y mulai dipakai pada editorial koran besar Amerika Serikat pada Agustus 1993. Generasi ini banyak menggunakan teknologi komunikasi instan seperti email, SMS, instan messaging dan media sosial seperti facebook dan twitter, instagram dan lain-lain. Sehingga dengan kata lain generasi $\mathrm{Y}$ adalah generasi yang tumbuh pada era internet booming (Hidayatullah et al., 2018: 241).

Karena dibesarkan oleh kemajuan teknologi, generasi milenial memiliki ciri-ciri yaitu kreatif, informatif, mempunyai passion, dan produktif. Generasi milenial memiliki perbedaan karakteristik dari generasi sebelumnya. Dibandingkan generasi sebelumnya, generasi milenial memiliki karakter yang unik berdasarkan wilayah dan kondisi sosialekonomi. Menurut Yoris Sebastian dalam bukunya Generasi Langgas Millennials Indonesia, ada beberapa keunggulan dari generasi milenial, yaitu ingin serba cepat, mudah berpindah pekerjaan dalam waktu singkat, kreatif, dinamis, melek teknologi, dekat dengan media sosial, dan sebagainya (Statistik, 2018).

\section{Minat Investasi}

Secara etimologi kata minat berasal dari bahasa Inggris "interest" yang berarti kesukaan, perhatian (kecenderungan hati pada sesuatu), keinginan. Berdasarkan Kamus Besar Bahasa Indonesia minat memiliki arti kecenderungan hati yang tinggi terhadap sesuatu, gairah, keinginan (KBBI Daring 2016). Menurut Prof. Dr. Iskandarwasid dan Dr. H. Dadang Sunendar, minat adalah perpaduan antara keinginan dan kemauan yang dapat berkembang. Sedangkan menurut Hilgad, minat adalah kecenderungan yang tetap untuk memperhatikan dan mengenang beberapa kegiatan (Iskandarwasid \& Sunendar, 2011: 113).

Investasi berasal dari bahasa Inggris "Investment" dari kata "invest" yang berarti menanam atau, "isthatmara" dalam bahasa Arab, yang berarti menjadikan berbuah, 
berkembang dan bertambah jumlahnya. Menurut istilah, Rahmawan (2005) menjelaskan investasi merupakan kepemilikan seseorang atau sebuah perusahaan atas barang yang tidak bergerak guna mendapatkan keutungan secara berkala atas penjualan dan umumnya dikuasai dalam waktu yang relatif panjang. Definisi tersebut serupa dengan yang diungkapkan oleh Kasmir dan Jakfar (2015), dimana kegiatan investasi dapat diartikan sebagai penanaman modal dalam suatu kegiatan yang memiliki jangka waktu yang relatif panjang dalam berbagai bidang usaha atau proyek yang membutuhkan dana dengan tujuan untuk memperoleh keuntungan (Pardiansyah, 2017: 340).

Minat berinvestasi masyarakat Indonesia terutama generasi milenial masih terbilang rendah, khususnya investasi di pasar modal syariah (Hana, 2019). Hal ini disebabkan oleh minimnya literasi mengenai pasar modal syariah. Padahal jika dilihat secara populasi, seharusnya Indonesia memiliki potensi yang tinggi dalam jumlah investor syariah karena penduduk Indonesia mayoritas adalah Muslim (Khotimah et al., 2011). Oleh karena itu, dalam rangka meningkatkan literasi masyarakat Bursa Efek Indonesia menyelenggarakan berbagai program edukasi pasar modal syariah salah satunya yaitu seminar pasar modal syariah. Program edukasi pasar modal syariah adalah kegiatan edukasi, literasi, inklusi pasar modal syariah yang dilakukan oleh Bursa Efek Indonesia baik secara reguler maupun kerjasama dengan pihak lain (BEI 2018).

\section{Seminar Pasar Modal Syariah}

Seminar adalah bentuk diskusi dengan tujuan memecahkan suatu masalah yang dilakukan secara ilmiah. Seminar berasal dari bahasa Latin yaitu "seminarum" yang berarti "tempat menanam benih". Secara terminologi, seminar merupakan sebuah pertemuan yang diselenggarakan berdasarkan suatu topik khusus yang dilaksanakan dengan interaksi tanya jawab yang dipimpin oleh seorang moderator. Biasanya seminar diadakan oleh para akademisi baik dari lembaga ataupun organisasi profesional maupun komersil (Ruangguru 2019).

Pasar modal syariah dapat diartikan sebagai pasar modal yang menerapkan prinsipprinsip sesuai syariah. Menurut Fatwa DSN MUI No. 40/DSN-MUI/X/2003 yang dimaksud dengan pasar modal syariah adalah pasar modal yang seluruh mekanisme kegiatannya telah sesuai dengan prinsip syariah (Hana, 2019: 372). Pasar modal syariah merupakan bagian dari industri pasar modal indonesia. Secara umum, kegiatan pasar modal syariah sejalan dengan pasar modal pada umumnya. Namun, ada beberapa karakteristik khusus pasar modal syariah yaitu produk dan mekanisme transaksi dalam pasar modal syariah tidak bertentangan dengan prinsip syariah (OJK 2017).

Seminar pasar modal syariah adalah program edukasi dan sosialisasi pasar modal yang diselenggarkan oleh Bursa Efek Indonesia. Seminar pasar modal syariah merupakan program edukasi pasar modal syariah yang bertujuan untuk menyebarluaskan informasi dan meningkatkan kesadaran (awareness) masyarakat tentang investasi di pasar modal syariah (BEI 2018).

\section{METODE PENELITIAN}

Penelitian ini merupakan jenis penelitian lapangan (field research). Penelitian lapangan (field research) adalah suatu penelitian yang dilakukan secara sistematis dengan mengangkat data yang ada di lapangan (Arikunto, 1995: 58). Adapun penelitian ini bersifat kualitatif dengan metode pengambilan sampel secara acak menggunakan teknik purposive sampling. Teknik purposive sampling merupakan teknik pengambilan sampel dengan cara 
menentukan berdasarkan kriteria untuk dijadikan sampel (Mubarok, 2018: 115). Sampel dipilih dari populasi generasi milenial di lingkungan Fakultas Ekonomi dan Bisnis Islam IAIN Kudus dengan kriteria sebagai berikut:

1. Mahasiswa merupakan generasi milenial.

2. Mahasiswa telah mengikuti mata kuliah Pasar Modal Syariah.

3. Mahasiswa telah mengikuti Sekolah Pasar Modal Syariah.

Penelitian ini menggunakan sumber data primer. Data primer merupakan data yang diperoleh secara langsung dari lapangan tanpa melalui pihak ke tiga (Prayoga, 2019: 139). Oleh karena itu, pengumpulan data dalam penelitian ini diperoleh dari wawancara kepada narasumber dengan menyebarkan kuisioner online menggunakan google form. Kemudian data atau informasi yang diperoleh dianalisis menggunakan analisa kualitatif sehingga penelitian ini dapat menghasilkan data deskriptif yang berupa kata-kata tertulis maupun lisan (J., Lexy \& Moelong, 1991: 3).

\section{PEMBAHASAN}

Investasi merupakan salah satu instrumen pembangunan untuk meningkatkan kesejahteraan masyarakat. Menurut Mumtaz (2010) terdapat 2 (dua) paradigma dalam berinvestasi. Pertama, investasi dipandang sebagai keinginan. Investasi dipandang sebagai keinginan jika seseorang yang memiliki kelebihan uang memilih untuk menabung uangnya daripada digunakan untuk berinvestasi. Kedua, investasi dipandang sebagai kebutuhan. Sebaliknya, investasi dipandang sebagai kebutuhan jika seseorang yang memiliki kelebihan uang lebih mengutamakan kepentingan investasi daripada menabung (Hana, 2019: 373).

Investasi di pasar modal merupakan salah satu alternatif investasi yang mudah untuk diakses oleh masyarakat. Akan tetapi, apabila dibandingkan dengan negara lain, antusias masyarakat Indonesia untuk melakukan investasi masih tergolong rendah. Hal ini disebabkan oleh minimnya literasi masyarakat mengenai pasar modal (Mega \& Semara, 2015: 105). Hasil Survei Nasional Literasi Keuangan dalam Roadmap Pasar Modal Syariah lebih dari $90 \%$ masyarakat Indonesia belum mengenal pasar modal. Sehingga jumlah penduduk Indonesia yang menggunakan instrumen pasar modal hanya sebesar kurang dari 1\% (Khotimah et al., 2011: 424).

Apabila dibandingkan dengan negara-negara Asia lainnya, seharusnya Indonesia memiliki potensi yang lebih besar dalam meningkatkan jumlah investor terutama investor efek-efek syariah di pasar modal syariah (Mubarok, 2018: 114). Padahal jika dilihat secara populasi, seharusnya Indonesia memiliki potensi yang tinggi dalam jumlah investor syariah karena penduduk Indonesia sebagian besar adalah Muslim (Khotimah et al., 2011). Akan tetapi, pada kenyataannya jumlah investor Indonesia dibandingkan dengan investor dari negara-negara Asia lainnya masih tergolong rendah yaitu hanya sebesar $0,14 \%$.

Pasar modal dibagi dalam 2 (dua) kategori. Pertama, pasar modal reguler merupakan pasar yang kegiatan transaksinya tidak menggunakan prinsip syariah. Kedua, pasar modal syariah merupakan pasar yang mulai dari instrumen yang dibeli sampai dengan proses kegiatan transaksinya menggunakan prinsip syariah (Hana, 2019: 369). Pasar modal adalah pasar yang menyediakan berbagai instrumen keuangan yang diperjualbelikan baik dalam bentuk saham, reksadana, obligasi, dan lain-lain. Sedangkan pasar modal syariah adalah pasar modal yang mekanisme dan prinsipnya tidak bertentangan dengan syariah (Albab \& Zuhri, 2019: 129). 
Berdasarkan hasil wawancara melalui penyebaran kuisioner online melalui google form pada tanggal 16-18 April 2020 kepada mahasiswa-mahasiswi Fakultas Ekonomi Bisnis Islam IAIN Kudus Program Studi Ekonomi Syariah angkatan 2017 terkumpul 8 kuisioner narasumber yang dapat dijadikan bahan analisis. Data yang diperoleh dapat digambarkan dalam diagram sebagai berikut:

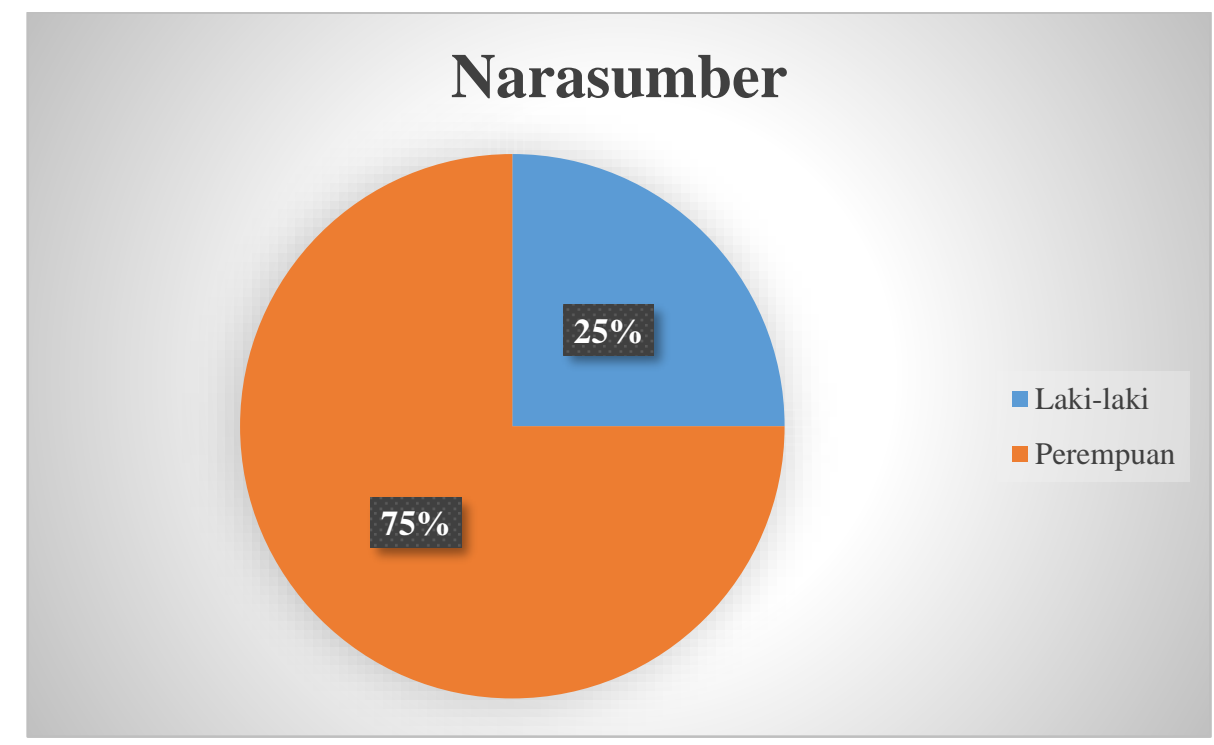

Gambar 1. 1 Jenis Narasumber

Dari hasil wawancara tersebut dapat diketahui bahwa $100 \%$ narasumber telah mengikuti mata kuliah Pasar Modal Syariah. Selain itu, mahasiswa-mahasiswi Fakultas Ekonomi Bisnis Islam IAIN Kudus Program Studi Ekonomi Syariah angkatan 2017 juga sudah pernah mengikuti Seminar Pasar Modal Syariah yang diselenggarakan oleh Bursa Efek Indonesia (BEI).

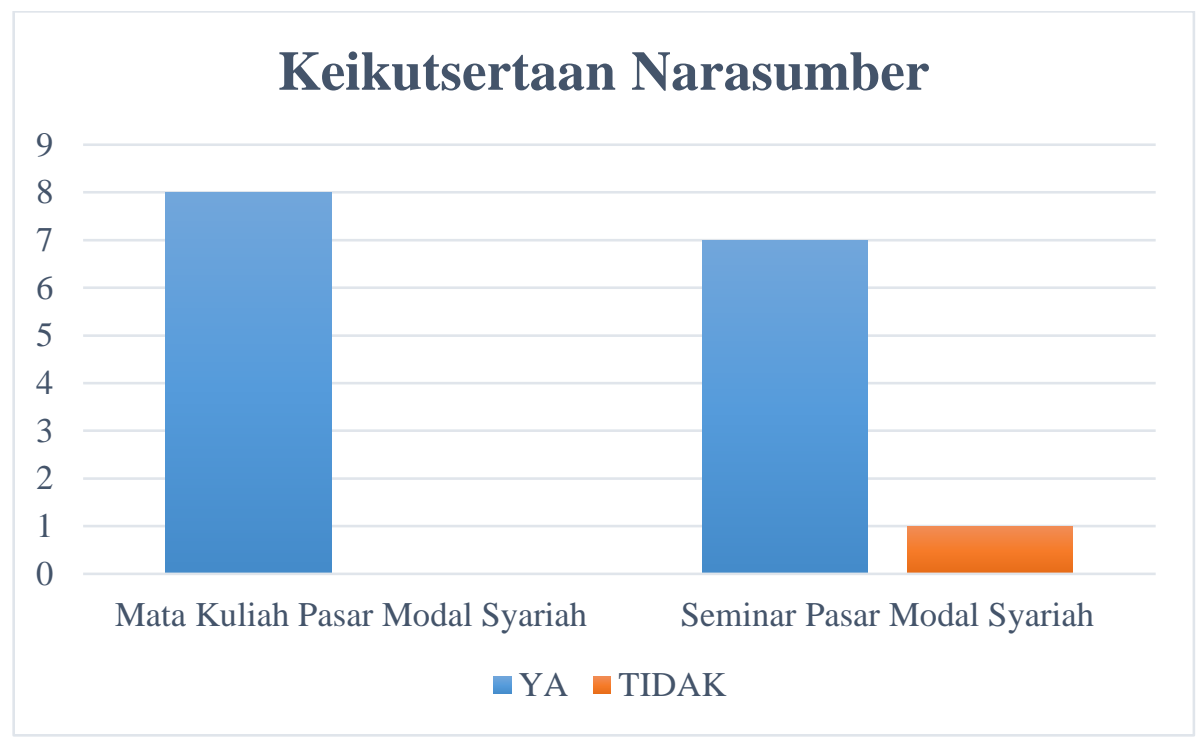

Gambar 1. 2 Informasi Keikutsertaan Narasumber 
Sebagian besar alasan narasumber mengikuti program edukasi ini yaitu berawal dari tugas yang bersifat wajib dari Fakultas Ekonomi Bisnis Islam IAIN Kudus sebagai bagian atas rangkaian kegiatan Praktik Kerja Lapangan (PKL). Akan tetapi, beberapa narasumber juga mengakui bahwa keikutsertaannya dalam Seminar Pasar Modal Syariah yang diselenggarakan oleh Bursa Efek Indonesia (BEI) tidak semata-mata karena kewajiban kampus. Namun, narasumber memang benar-benar tertarik dan ingin mengetahui lebih banyak mengenai seluk beluk investasi terutama di pasar modal syariah. Hal ini terbukti dengan keikutsertaan beberapa narasumber dalam Seminar Pasar Modal Syariah yang pernah diselenggarakan oleh Galeri Investasi Syariah (GIS) di lingkungan kampus IAIN Kudus.

Menurut para narasumber adanya Seminar Pasar Modal Syariah ini dapat membuka dan menambah wawasan, pengetahuan serta pengalaman dari para ahli mengenai pasar modal khususnya pada sektor instrumen-instrumen efek syariah. Oleh karena itu, keberadaan program edukasi Seminar Pasar Modal Syariah ini dianggap sangat penting untuk mengedukasi masyarakat awam mengenai investasi di pasar modal syariah. Mengingat kesadaran untuk berinvestasi masyarakat Indonesia tergolong cukup rendah akibat kurangnya literasi dan informasi investasi di pasar modal syariah. Sehingga, dengan adanya Seminar Pasar Modal Syariah diharapkan mampu mendorong minat berinvestasi mahasiswa sebagai generasi milenial yang melek finansial agar dapat berkontribusi lebih banyak di pasar modal syariah.

Berdasarkan data dari www.idx.co.id pada akhir tahun 2018 sampai akhir bulan februari tahun 2019 jumlah investor saham di Bursa Efek Indonesia (BEI) secara keseluruhan sebanyak 170.362 investor aktif. Hal ini menunjukkan bahwa adanya peningkatan jumlah investor sebesar 32\% dari tahun 2018 kuartal akhir. Dalam 2 tahun terakhir, lebih dari $100 \%$ peningkatan investor aktif didominasi oleh generasi Milenial Cinta Investasi (MICIN) (Albab \& Zuhri, 2019: 130).

Mahasiswa-mahasiswi Fakultas Ekonomi Bisnis Islam IAIN Kudus Program Studi Ekonomi Syariah angkatan 2017 mayoritas sudah mempunyai Rekening Dana Nasabah (RDN). Hal ini menunjukkan bahwa mahasiswa-mahasiswi Fakultas Ekonomi Bisnis Islam IAIN Kudus Program Studi Ekonomi Syariah angkatan 2017 cukup antusias untuk berinvestasi di pasar modal syariah. Namun, mayoritas narasumber mengaku ada beberapa hambatan untuk berinvestasi. Salah satu hambatan yang paling dominan yaitu modal yang terbatas menghambat kegiatan narasumber dalam berinvestasi di pasar modal syariah. Hal ini terjadi karena mahasiswa kebanyakan belum berpenghasilan dan hanya bisa mengandalkan uang saku yang jumlahnya cukup minim. Selain itu, pemahaman dan pengalaman investasi yang masih rendah juga menjadi salah satu faktor penghambat untuk aktif berinvestasi. Akan tetapi, tingkat risiko kerugian masih menjadi momok menakutkan bagi investor milenial yang tergolong masih baru dalam dunia investasi. Sehingga, para narasumber sebagai investor pemula cenderung berfikir dua kali untuk terjun langsung dalam aktivitas investasi. 


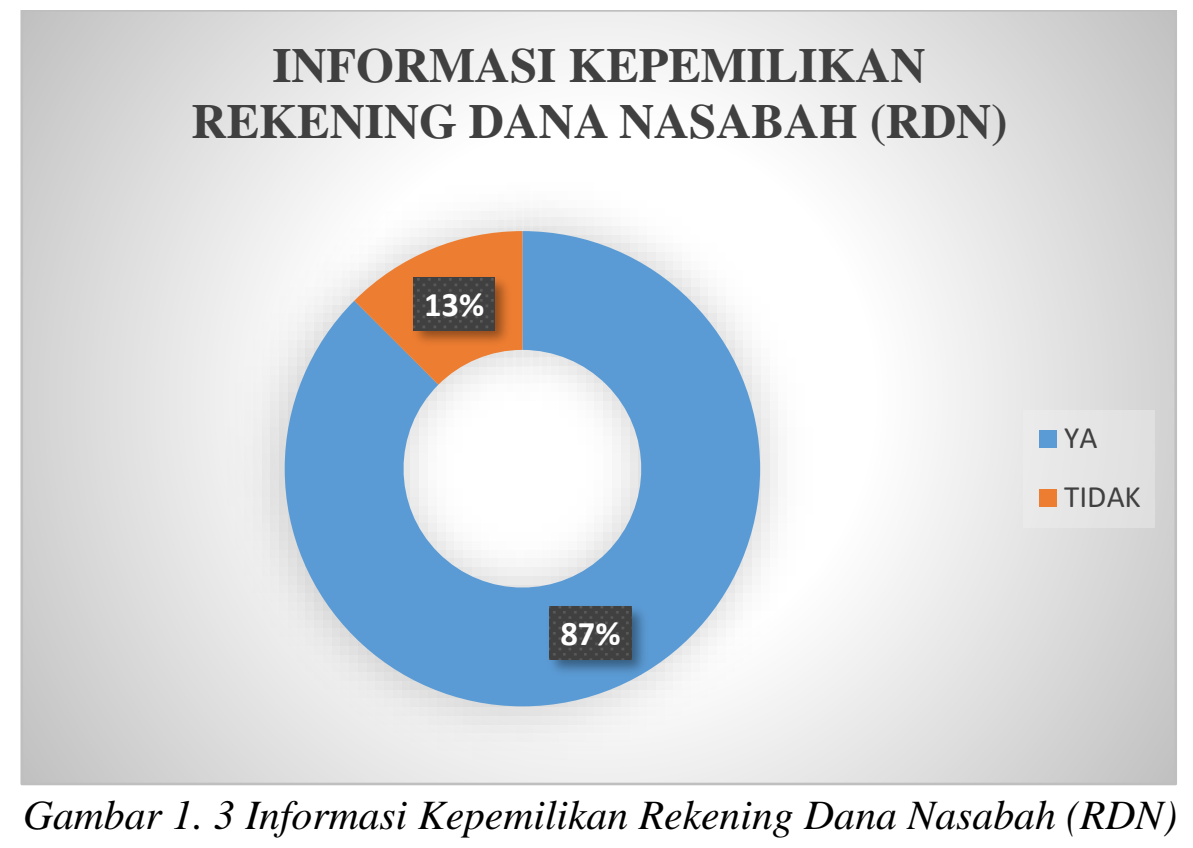

\section{SIMPULAN}

Berdasarkan hasil dan pembahasan di atas, dapat disimpulkan bahwa program edukasi Seminar Pasar Modal Syariah cukup efektif dalam memoderasi minat berinvestasi generasi milenial terutama di kalangan mahasiswa-mahasiswi Fakultas Ekonomi Bisnis Islam IAIN Kudus Program Studi Ekonomi Syariah angkatan 2017. Hal ini memberikan arti bahwa melalui program edukasi Seminar Pasar Modal Syariah literasi tentang pasar modal syariah meningkat sehingga mampu mendorong minat berinvestasi generasi milenial. Selain itu, hasil dan pembahasan juga menunjukkan bahwa keterbatasan dan minimnya modal masih menjadi faktor dominan penghambat minat investasi generasi milenial. Memang tidak mudah menyelesaikan masalah modal yang menjadi penghambat berinvestasi generasi milenial yang kebanyakan berasal dari kalangan mahasiswa yang notabene belum berpenghasilan dan masih mengandalkan minimnya uang saku dari orang tua. Oleh karena itu, untuk meminimalisir faktor tersebut pihak-pihak yang berkaitan diharapkan dapat memberi solusi terbaik bagi generasi milenial yang ingin terjun dalam dunia investasi. 


\section{PUSTAKA ACUAN}

Albab, A. U., \& Zuhri, S. (2019). Pengaruh Manfaat, Pengetahuan, dan Edukasi terhadap Minat Mahasiswa dalam Berinvestasi di Pasar Modal Syariah. Li Falah : Jurnal Studi Ekonomi Dan Bisnis Islam, 4(1), 129-138.

Arikunto, S. (1995). Dasar-dasar Research. Bandung: Tarsoto.

BEI. (2018). Edukasi Pasar Modal Syariah. Diakses dari https://idx.co.id/idxsyariah/edukasi-pasar-modal-syariah/. (17 Maret 2020)

Faiza, A., Firda, S. J., dkk. (2018). Arus Metamorfosa Milenial. Kendal: Penerbit Ernest.

Hidayatullah, S., Waris, A., dkk. (2018). Perilaku Generasi Milenial dalam Menggunakan Aplikasi Go-Food. Jurnal Manajemen \& Kewirausahaan, 6(2), 240-249.

Iskandarwasid, \& Sunendar, D. (2011). Strategi Pembelajaran Bahasa. Bandung: Remaja Rosdakarya.

J., Lexy \& Moelong. (1991). Metodologi Penelitian Kualitatif. Bandung: Remaja Rosdakarya.

KBBI. (2016). Kamus Besar Bahasa Indonesia (KBBI) Daring. Diakses dari https://kbbi.kemdikbud.go.id/. (17 Maret 2020)

Kharis Fadlullah Hana. (2019). Efektivitas Literasi Melalui Game Nabung Saham Go terhadap Keputusan Membeli Saham Syariah. Jurnal Ekonomi Syariah, 7(2), 367385.

Khotimah, H., Warsini, S., dkk. (2011). PENGARUH SOSIALISASI DAN PENGETAHUAN TERHADAP MINAT INVESTOR PADA EFEK SYARIAH DI PASAR MODAL (Survei Pada Nasabah PT Danareksa Sekuritas Cabang FE-UI Depok). Jurnal Account, 423-433.

Mega, I. P., \& Semara, J. (2015). Kemampuan Pelatihan Pasar Modal Memoderasi Pengaruh Pengetahuan Investasi Dan Penghasilan Pada Minat Berinvestasi Mahasiswa. Jurnal Ilmiah Akuntansi Dan Bisnis, 10(2), 105-118.

Mubarok, F. K. (2018). Peran Sosialisasi dan Edukasi dalam Menumbuhkan Minat Investasi di Pasar Modal Syariah. Inovasi, 14(2), 113-122. 
OJK. (2017). Pasar Modal Syariah. Diakses dari https://www.ojk.go.id/id/kanal/syariah/tentang-syariah/pages/pasar-modalsyariah.aspx. (3 Mei 2020)

Pardiansyah, Elif. (2017). Investasi dalam Perspektif Ekonomi Islam: Pendekatan Teoritis dan Empiris. Economica: Jurnal Ekonomi Islam, 8(2), 337-373.

Prayoga, Y. (2019). PENGARUH EDUKASI DAN SOSIALISASI SEKOLAH PASAR MODAL BURSA EFEK INDONESIA TERHADAP MOTIVASI MEMBELI SAHAM DI GALERI INVESTASI UNIVERSITAS LABUHAN BATU. ECOBISMA (JURNAL EKONOMI, BISNIS DAN MANAJEMEN), 6(2), 137-144.

Ruangguru. (2019). Seminar: Pengertian, Definisi, Ciri-ciri, Susunan, Fungsi, dan Pihak yang Terlibat. Diakses dari https://www.ruangguru.co.id/. (3 Mei 2020)

Statistik, B. P. (2018). STATISTIK GENDER TEMATIK: PROFIL GENERASI MILENIAL INDONESIA. Jakarta: Kementerian Pemberdayaan Perempuan dan Perlindungan Anak.

Tandelilin, E. (2010). Portofolio dan Investasi. Yogyakarta: Kanisius.

Yuswohady. (2016). Millennial Trends 2016. Diakses dari Www.Yuswohady.Com. (17 Maret 2020) 